\title{
A Case of Intravenous Pyogenic Granuloma Originating in the External Jugular Vein
}

\author{
Sun Woo Kim ${ }^{\mathbb{D}}$, So Yean Kim, Seung Ho Noh, and Sang Hyuk Lee $\mathbb{C}$ \\ Department of Otorhinolaryngology-Head and Neck Surgery, Kangbuk Samsung Hospital, \\ Sungkyunkwan University School of Medicine, Seoul, Korea
}

외경정맥에 발생한 정맥 내 화농성 육아종 1예

김선우 · 김소연 · 노승호 · 이상혁

성균관대학교 의과대학 강북삼성병원 이비인후과학교실

Received January 30, 2018

Revised April 3, 2018

Accepted May 23, 2018

Address for correspondence

Sang Hyuk Lee, MD

Department of Otorhinolaryngology-

Head and Neck Surgery,

Kangbuk Samsung Hospital,

Sungkyunkwan University

School of Medicine,

29 Saemunan-ro, Jongno-gu,

Seoul 03181, Korea

Tel $+82-2-2001-2269$

Fax $+82-2-2001-2273$

E-mail entlsh@hanmail.net
Intravenous pyogenic granuloma (IVPG), also known as intravenous lobular capillary hemangioma, is an extremely rare form of vascular tumor which derives from the lumen of a vein of the head and neck and upper extremities. The treatment of choice is complete local excision of a small portion of the vein. Since first report in 1979, IVPG has been reported in no more than 60 reports abroad. To our knowledge, IVPG originating in the external jugular vein has never been reported in Korea but has important clinical implication. Accurate preoperative diagnosis of neck mass originating in jugular vein is important to plan operative procedures to avoid vascular injury, excessive bleeding, or incomplete excision. Preoperative radiologic examinations such as ultrasonography, computed tomography are useful as first-line diagnostic tools for differential diagnosis of movable neck mass. With a review of literature, the author reports a case of IVPG arising from the left external jugular vein in a 31-year-old male who complained about a palpable neck mass. This patient was successfully managed by ligation and excision of the vein without any complication and no recurrence was found after 6 months. Korean J Otorhinolaryngol-Head Neck Surg 2019;62(5):307-11

Key Words External jugular vein · Intravenous lobular capillary hemangioma Intravenous pyogenic granuloma · Pyogenic granuloma.

\section{서 론}

화농성 육아종(pyogenic granuloma)은 일반적으로 피부 및 점막에서 발생하는 $0.5 \sim 2.0 \mathrm{~cm}$ 정도 크기의 폴립 모양 양성 혈 관종으로 소엽 모세혈관종(lobular capillary hemangioma) 으로도 불린다. 흔히 임신이나 경구 피임약의 복용, 피부나 점막의 국소적인 외상으로 인한 염증 등과 관련되어 있는 것 으로 알려져 있으며 주로 피부, 구강 병변, 비강 점막 등에서 나타나고, ${ }^{1)}$ 전체 피부 결절 중 $0.5 \sim 5 \%$ 를 차지한다. ${ }^{2,3)}$

This is an Open Access article distributed under the terms of the Creative Common Attribution Non-Commercial License (https://creativecommons.org/licenses/by-nc/4.0) which permits unrestricted non-commercial use, distribution, and reproduction in any medium, provided the original work is properly cited.
정맥 내 화농성 육아종(intravenous pyogenic granuloma, IVPG)은 1979년 Cooper 등 ${ }^{4}$ 에 의해 처음 기술되었으며, 정 맥 내에서 발생하는 드문 형태의 화농성 육아종으로 모세혈 관의 증식에 의해 형성된 소엽의 형태를 보인다. IVPG의 병 리 기전으로 일부 저자들은 선천적인 정맥 혈관종으로 기술 하지만,5) 혈관의 과다 증식을 유발하는 외상이나 감염에 의 해서도 발생하며 ${ }^{6)}$ 호르몬과 관련되어 발생된다는 보고가 있 으나 ${ }^{7)}$ 아직 정확한 병리 기전은 밝혀지지 않았다. ${ }^{8)}$ 주로 두 경부 및 상지의 혈관에서 발생하며 모든 연령층에서 발생 가 능하나 30 대의 발생이 가장 흔하고 여성에서 호발하는 것으 로 알려져 있다. ${ }^{9,10)}$

IVPG는 임상적으로 진단이 어려운 종양으로, 정맥 내에 
종물이 확인되면, 정맥 내 혈전, 정맥 내 유두모양 내막 증식 증, 혈관 육종 등의 감별이 필요하다. 초음파 검사, 자기공명 영상, 컴퓨터단층촬영 검사 등 영상 검사가 감별 진단에 도 움이 될 수 있다. ${ }^{11}$ 하지만 정확한 진단을 위해서는 조직학적 확인이 필요하다. IVPG의 치료는 정맥을 포함한 종괴의 국 소 절제이며 수술 후 예후는 좋은 것으로 알려져 있다. ${ }^{12-14)}$

IVPG는 발생 빈도가 낮고 임상적인 특징 또한 두드러지 지 않아 매우 드물게 보고되고 있다. 문헌 고찰 상 현재까지 보고된 60예의 정맥 내 화농성 육아종 중에서 외경정맥에 발 생한 경우는 3 예가 있었으나 국내에는 아직 보고된 바가 없 다. ${ }^{915)}$ 저자들은 좌측 경부의 무통성 종물을 주소로 내원한 31세 남자에서 진단 및 치료 목적으로 절제 생검을 시행하여 좌측 외경정맥 내 화농성 육아종으로 확진된 1예를 치험하 였기에 이를 문헌 고찰과 함께 보고하는 바이다.

\section{증 례}

31세 남자 환자가 내원 2개월 전부터 촉지된 좌측 경부의 무통성 종물을 주소로 본원 이비인후과로 내원하였다. 특이
병력은 없었던 자로, 이학적 검사 시 좌측 흥쇄유돌근의 외 측 피하에서 $1 \mathrm{~cm}$ 크기의 원형 모양의 단발성 종괴가 촉지되 었으며, 촉진 시에 움직이며 부드럽게 만져지고, 통증 및 압 통을 동반하지 않았다. 수술 전 시행한 혈액검사, 심전도, 소 변검사 및 흥부 방사선 검사에서 모두 정상 범위 소견을 보였 다. 유피낭종(epidermoid cyst), 신경종(neurogenic tumor) 을 의심하여 시행한 경부 컴퓨터단층촬영 검사에서 조영제 투여 후 좌측 외경정맥 내에서 약 $0.5 \times 0.5 \mathrm{~cm}$ 의 비교적 경 계가 명확하고 불균질한 음영을 보이는 종괴가 관찰되었으 며, 그 외 근육, 신경, 림프 조직에서 관찰되는 종양은 없었다 (Fig. 1).

저자들은 이상의 결과로 정맥 내 혈전, 정맥 내 유두모양 내막 증식증, 혈관 육종 등을 의심하여 진단 및 치료의 목적 으로 수술적 제거를 계획하였다. 국소마취하에 피부 절개 후 좌측 외경정맥을 노출하였고, 외경정맥 내 $1 \times 1 \mathrm{~cm}$ 크기의 회백색 종양이 육안적으로 관찰되었다(Fig. 2). 이 종양은 외 경정맥 내에서 약간의 가동성을 보였으나 크게 움직이지는 않았으며, 주변 조직이나 혈관과의 유착은 보이지 않았다. 종 양을 포함하여 외경정맥을 결찰하였고, 외경정맥과 함께 종
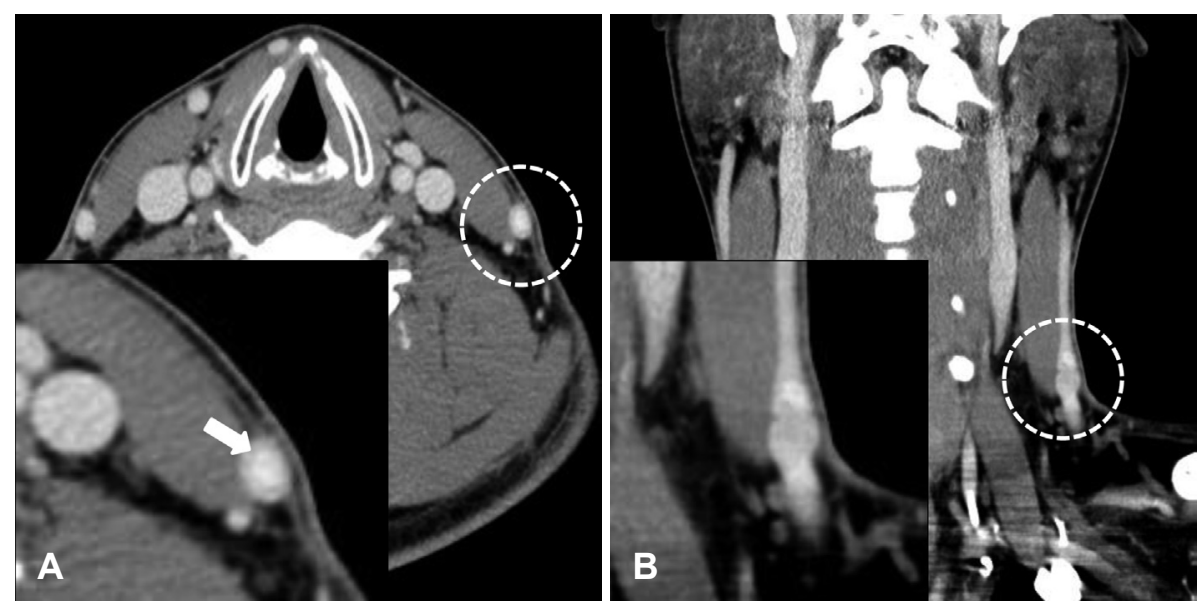

Fig. 1. Neck CT. Preoperative axial $(A)$, sagittal $(B)$ view of enhanced neck CT scan shows the ovoid, well circumscribed, $0.5 \times 0.5 \mathrm{~cm}$ sized heterogenous enhanced mass (arrow) in the left external jugular vein.
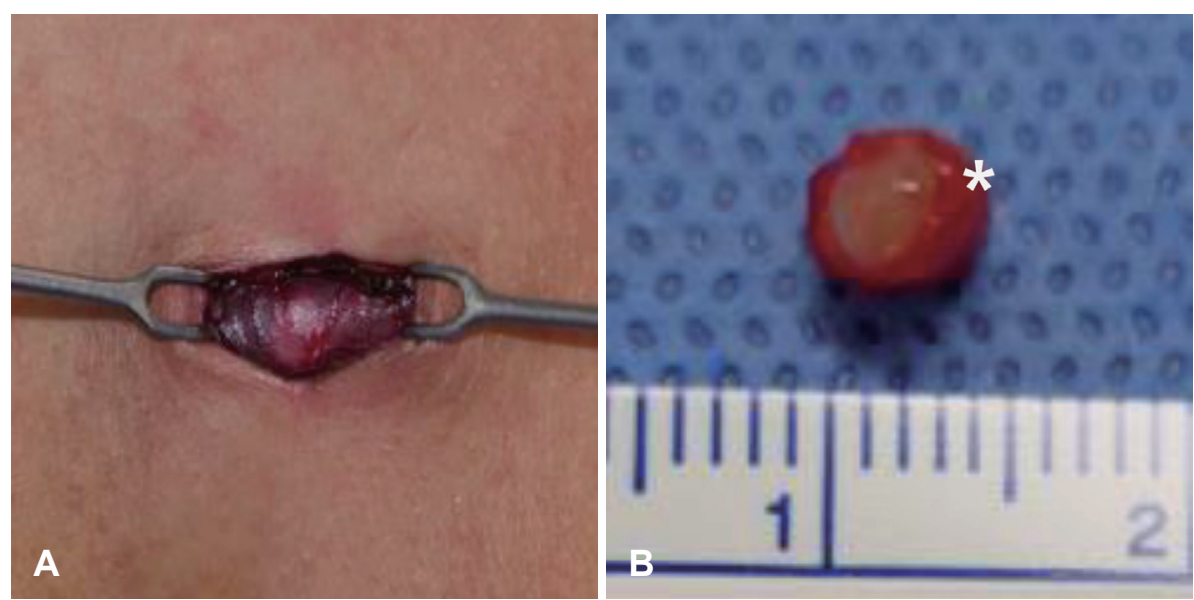

Fig. 2. Intraoperative photograph. Gross findings of intravenous pyogenic granuloma in external jugular vein (A). Intraoperative photograph shows $0.5 \times 0.5 \mathrm{~cm}$ sized well lobulated, soft, pale mass in the external jugular vein (asterisk) (B). 

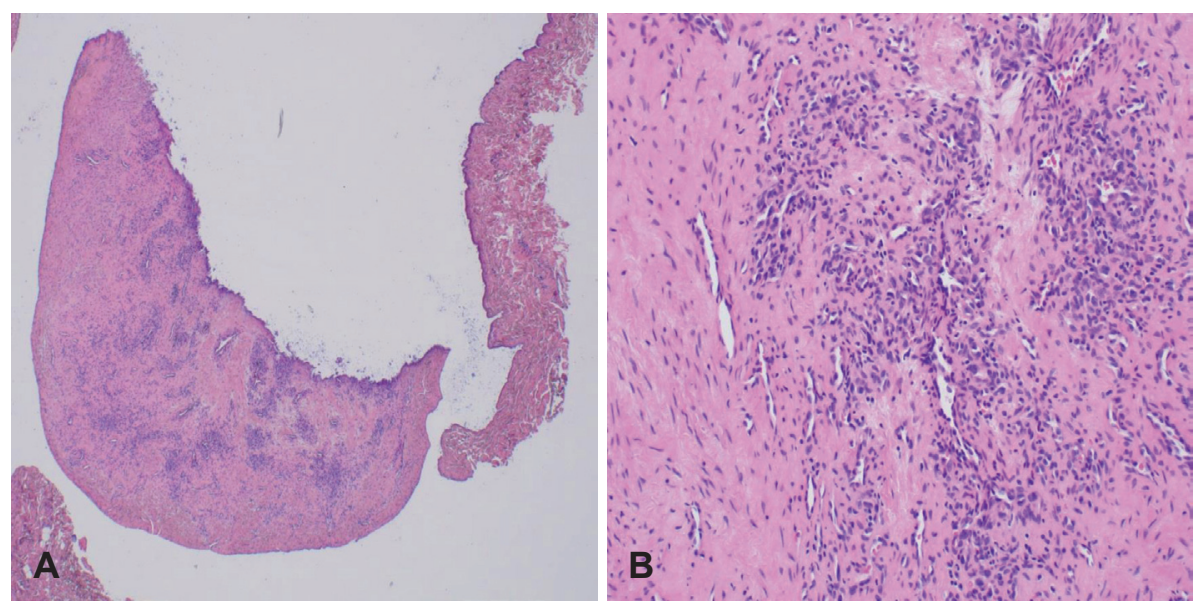

Fig. 3. Pathologic finding. Histopathologic finding of intravenous pyogenic granuloma. Capillaries are arranged in a lobular manner surrounded by fibromyxoid stroma (H\&E stain, $\times 40)(A)$. Tumor composed of lobulated capillaries and lined by endothelial cells and supported by fibrous stroma (H\&E stain, $\times 400)$ (B). H\&E: hematoxylin and eosin.

양을 절제하였다. 이후 피하조직 및 피부를 봉합하였고 수술 을 종료하였다.

수술 후 확인된 병리 소견상 외경정맥 내에 회백색 종양이 관찰되었고, 종양 내부에는 증식된 모세혈관이 소엽성 배열 을 이루고 있었으며, 이 모세혈관들은 내피세포로 구성되어 있었다. 또한, 모세혈관 사이에 콜라겐성 기질로 이루어진 섬 유점액 기질을 관찰할 수 있었다(Fig. 3). 환자는 수술 후 특 별한 합병증을 보이지 않았고, 수술 후 6개월간의 추적 검사 에서 재발의 흔적이나 혈류 장애 및 기능적 이상 소견은 관찰 되지 않았다.

\section{고 찰}

IVPG는 1979년 Cooper 등 ${ }^{4}$ 에 의해 처음 기술되었으며 드문 형태의 화농성 육아종으로, 주로 두경부 및 상지의 정 맥에 발생한다. 남성보다 여성에게 호발하는 것으로 알려져 있으며, 모든 연령층에서 발생 가능하나, 주로 30대에 호발한 다. ${ }^{9,10)} \mathrm{IVPG}$ 는 무통성 종물이 주된 증상으로 이외 다른 임 상적 특징이 뚜렷하지 않아 감별 진단이 비교적 어려워, 영상 검사가 진단에 도움이 될 수 있다.

IVPG는 초음파 검사를 이용하여 저에코 음역 내에 과혈관 성이 동반된 혈관 내 병변을 찾는 것이 감별진단에 도움이 된 다고 일부 저자들은 기술하였다. ${ }^{11}$ 자기공명영상에서 IVPG 는 $\mathrm{T} 1$ 강조영상 및 조영증강 후 영상에서 주변 피부 및 근육 와 같은 등신호 강도를 보이며, T2 강조영상 및 조영증강 후 영상에서는 정맥보다 등신호 혹은 고신호 영상으로 보인다고 알려져 있다. ${ }^{10,11}$ 컴퓨터단층촬영에서는 조영제 투여 전 저음 역의 종괴 및 조영제 투여 후 불균질한 음영을 보이는 혈관 내 병변으로 관찰된다. 본 증례의 경우 시행한 경부 컴퓨터단 층촬영에서 조영제 투여 후 좌측 외경정맥 내에서 $0.5 \times 0.5 \mathrm{~cm}$
의 비교적 경계가 명확하고 불균질한 음영을 보이는 종괴가 관찰되었다.

이러한 영상 검사들이 감별 진단에 도움이 될 수 있지만, 정확한 진단을 위해서는 조직학적 검사가 필요하다. IVPG의 육안적 소견으로는 유경성, 외장성 증식을 하는 용종의 형태 를 띠며, 표면은 착각화(parakeratotic) 혹은 비각화(nonkeratinized) 상피로 덮여 있는데 염증이나 궤양이 흔하게 발견 된다. ${ }^{16)}$ 특징적인 병리학적 소견으로 저배율에서 종양 내에 많 은 모세혈관이 소엽 형태를 이루고 있으며 고배율에서는 모 세혈관이 내피세포로 구성되어 있고 모세 혈관 사이에는 콜 라겐성 기질로 이루어진 섬유점액 기질로 구성되어 있다.5) 또 한, 내피 표지자의 면역적 염색(CD34, ulex europaeus agglutinin, factor VIII-연관 항원 등)을 이용하면 진단에 도움이 될 수 있다. ${ }^{17,18)}$

정맥 내 화농성 육아종은 정맥 내 혈전, 정맥 내 유두모양 내막 증식증, 혈관 육종 등과의 감별이 필요하다. 정맥 내 혈 전은 주로 수술받은 환자이거나, 누워 지내는 환자에게서 발 생한다는 점과 영상 검사에서 혈류 공급이 되지 않는 종괴가 관찰된다는 점에서 감별이 가능하다. ${ }^{19)}$ 정맥 내 유두모양 내 막 증식증은 주로 혈전에 의해 발생하며, 정맥 내 화농성 육 아종에서 특징적으로 보이는 엽상 배열은 보이지 않고 기질화 과정에서 여러 단계의 섬유소 혈전이 함유되어 있는 것이 감 별점이다. ${ }^{11,14)}$ 혈관 육종은 회백색의 단단한 종물로 관찰되며 정맥 내 화농성 육아종과 육안적으로 비슷하게 관찰된다. 병 리 조직학적 소견상 다형성(polyporphism)이 관찰되며 정맥 내 화농성 육아종과는 달리 소엽 형태를 보이진 않는다는 점 에서 감별할 수 있다. ${ }^{19)}$

정맥 내 화농성 육아종의 치료로는 정맥을 포함한 완전 국 소 절제이며, 수술 후 예후는 좋고 재발은 적은 것으로 알려 져 있다. 본 예에서는 외경정맥을 포함한 종양의 국소 절제를 
시행하였으며 6 개월간의 추적 검사에서 재발하지 않았다.

문헌 고찰 상 Loftus 등1ㅣㅇㅔ 의해 현재까지 약 60예의 정맥 내 화농성 육아종이 보고되었으나, 국내에서 외경정맥에 발 생한 화농성 육아종이 보고된 경우는 없었다. 정맥에서 기원 한 경부 종물의 빈도는 비교적 낮기 때문에 경부의 종물을 주소로 내원한 환자에서 감별 진단 시 간과하기 쉽다. 경부에 서 가동성의 종물로 촉지되는 경우 낭종(cyst), 피하의 지방 종(lipoma), 반응성 림프절 등으로 진단되는 경우가 흔하나, 경정맥 주행 경로에 위치한 종물인 경우 IVPG와 같이 정맥 내에서 기원한 경우도 고려하여야 함을 본 증례는 시사하고 있다. 임상적으로 경부 종물의 수술적 치료 전 진단 목적으로 세침 흡입 세포 검사(fine needle aspiration) 등을 시행하는 경우가 많은데, 혈관 내에 발생한 종물에서는 혈관 천자로 인한 혈종이나 출혈 등의 위험성이 커질 수 있어 주의가 필요 하다. 이러한 경우 경부 초음파 검사는 바로 시행할 수 있는 우선적인 비침습적인 검사로서 혈관의 직경이 정상에 비해 커져 있는 소견을 보이거나 혈관 내 음영의 차이를 통해 혈 관 내 병변의 유무를 비교적 쉽게 판별할 수 있어 유용한 진 단 도구로 사용된다. 본 증례에서는 조영증강 경부 전산화단 층촬영을 통해 혈관 내 병변이 확인되었으나, 경부 초음파 검 사를 우선적으로 시행한다면 비용대비 효과를 최대화하고 방사선 유해, 조영제 부작용의 가능성을 방지할 수 있다고 사 료된다.

경정맥에서 기원한 종물인 경우 경정맥 혈전증과 반드시 감별하여야 하는데, 이는 감염되어 혈관염, 폐색전증, 패혈증 등 심각한 전신 합병증으로 이어질 수 있어 조속한 치료와 추적 관찰이 필요하기 때문이다. 따라서 경부 초음파, 컴퓨터 단층촬영 등을 이용해 종물의 위치 및 기원에 대한 정확한 평 가가 외과적 치료 이전에 선행되는 것이 중요함을 본 증례에 서 시사하고 있다.

또한, 경부 종물의 양상으로 촉지될 수 있는 경정맥의 질환 으로 경정맥 확장증(Jugular vein phlebectasia)이 있어 감별 이 필요하다. 이 질환은 내경정맥, 외경정맥, 전경정맥, 상대 정맥, 문맥, 복재정맥, 안면정맥 등에 모두 나타날 수 있는 질 환으로 기침, 재채기, valsalva법 시행 등의 흥곽 내압을 올리 는 행위 시에 무통성, 압축 가능한 낭종의 경부 종괴로 나타 난다는 특징이 있어 이학적 검사 시 감별할 수 있다. ${ }^{20)}$ 특히 경정맥 확장증은 병변이 압통성인 경우, 크기가 점점 커지는 경우, 정맥성 와류잡음이 심한 경우, 정맥염이나 혈전의 생성 가능성이 있는 경우 등을 제외하고는 별다른 합병증이 없는 완전한 양성 국한성 질환이며 비침습적 방법으로 확진 가능 하므로 경과 관찰 및 보존적 치료를 하는 것이 원칙이다. ${ }^{21)}$ 따라서 경부 종물을 주소로 내원하는 경우 불필요한 수술적
인 치료를 피하기 위해서는 정맥에 기원한 질환을 감별 진단 에 고려하며 비침습적인 진단 방법을 이용하여 진단하는 것 이 필요하다고 사료된다.

내경정맥은 경막의 $\mathrm{S}$ 상 정맥동과 안면정맥이 모여 형성된 후 총경동맥, 미주신경과 함께 주행하며, 외경정맥은 목의 외 측면의 표면 가까이에서 흥쇄유돌근(Sternocleidmastoid muscle)을 따라 위치하며 하악 부근에서 더 얇은 혈관의 형 태로 주행한다. 외경정맥은 흥쇄유돌근의 바깥에 위치하여 내경정맥보다 표면적으로 주행하고 있어 이학적 검사에서 시 진이나 촉진을 통해 정맥의 크기와 위치를 비교적 용이하게 확인할 수 있다. 이러한 차이로 내경정맥에서 기원한 종물 에 서보다 외경정맥에서 기원한 종물인 경우보다 명확하게 종물 을 촉지할 수 있으며 환자가 빠르게 종물을 자각할 확률이 높아질 것으로 사료된다. 문헌 고찰 상 내경정맥에서 발생한 화농성 육아종의 경우 환자의 주관적 증상은 없었고 경부 초음파상 우연히 발견된 증례가 보고되어 있으명) 본 증례에 서는 직경 $5 \mathrm{~mm}$ 정도의 비교적 작은 병변임에도 환자는 2개 월 전부터 분명히 만져지는 경부 종물을 주소로 본원을 내원 하였다.

기존에 보고된 내경정맥에 발생한 IVPG의 경우 내경정맥 을 결찰하여 종물을 제거하였는데, 본 증례와 비교해 보았을 때 외경정맥의 IVPG를 외과적으로 치료함에 있어서는 혈관 측부 순환이나 양측 경정맥의 개통성에 대한 고려가 크게 필 요하지 않다고 사료된다. 외경정맥은 양측으로 결찰하여도 후 유증을 남기지 않으나 양측의 내경정맥을 동시에 결찰 또는 희생하는 것은 중심 정맥압(central venous pressure)을 증가 시킴으로써 뇌압 상승, 경부나 안면의 부종과 통증 등이 나 타날 수 있어 한쪽은 복구하는 것이 바람직한 것으로 알려 져 있다.22)

저자들은 경부의 종물을 주소로 내원한 환자에서 문진 및 영상의학적 검사, 수술적 치료 및 조직 검사를 통해 외경정 맥에 발생한 정맥 내 화농성 육아종을 치험하였기에 문헌고 찰과 함께 보고하는 바이다.

\section{ORCID}

Sang Hyuk Lee $\quad$ https://orcid.org/0000-0003-4412-3486

Sun Woo Kim https://orcid.org/0000-0002-2894-1334

\section{REFERENCES}

1) Kim NY, Choi SM, Kim CH, Oh KK. Lobular capillary hemangioma (pyogenic granuloma). Korean J Otorhinolaryngol-Head Neck Surg 1994;37(6):1293-7.

2) Patrice SJ, Wiss K, Mulliken JB. Pyogenic granuloma (lobular capillary hemangioma): a clinicopathologic study of 178 cases. Pediatr Dermatol 1991;8(4):267-76.

3) Sills ES, Zegarelli DJ, Hoschander MM, Strider WE. Clinical diagnosis 
and management of hormonally responsive oral pregnancy tumor (pyogenic granuloma). J Reprod Med 1996;41(7):467-70.

4) Cooper PH, McAllister HA, Helwig EB. Intravenous pyogenic granuloma: a study of 18 cases. Am J Surg Pathol 1979;3(3):221-8.

5) Werner JA, Dünne AA, Folz BJ, Rochels R, Bien S, Ramaswamy A, et al. Current concepts in the classification, diagnosis and treatment of hemangiomas and vascular malfomations of the head and neck. Eur Arch Otorhinolaryngol 2001;258(3):141-9.

6) Cera C, Calvagna C, Sgorlon G, Zamolo F, Pancrazio F, Adovasio R. Internal jugular vein pyogenic capillary hemangioma: a case report. Ann Vasc Surg 2015;29(2):361.e5-7.

7) Duggal P, Chaturvedi P, Pai PS, Nair D, Juvekar SL, Rekhi B. Internal jugular vein vascular malformation presenting as mass at root of neck: a case report. BMC Ear Nose Throat Disord 2009;9:5.

8) Wu Z, Cheng W, Wang S, Chen Z. Pyogenic granuloma in the internal jugular vein. Eur Heart J 2010;32(6):772-3.

9) Ahn SE, Park JS, Ryu KN, Jin W, Park SY. Intravenous lobular capillary hemangioma occurring in the cephalic vein of a 39-year-old adult. J Clin Ultrasound 2014;42(6):375-8.

10) Pradhan S, Bazan H, Salem R, Gusberg RJ. Intravenous lobular capillary hemangioma originating in the iliac veins: a case report. $\mathrm{J}$ Vasc Surg 2008;47(6):1346-9.

11) Loftus WK, Spurrier AJ, Voyvodic F, Neuhaus SJ, James CL. Intravenous lobular capillary haemangioma (pyogenic granuloma): a case report and a review of imaging findings as reported in the literature. J Med Imaging Radiat Oncol 2018;62(2):217-23.

12) Ghekiere $O$, Galant $C$, Berg B. Intravenous pyogenic granuloma or intravenous lobular capillary hemangioma. Skeletal Radiol 2005; 34(6):343-6.

13) Kim DH, Kim DH, Kim HM, Lee JH, An BW. Intravenous pyogenic granuloma of the finger. J Korean Soc Surg Hand 2013;18(4):173-7.

14) Matsuzaki K, Imamura $Y$, Ozawa M, Nakajima T, Ikeda A, Konishi $\mathrm{T}$, et al. Intravenous lobular capillary hemangioma in the subclavian vein. Ann Thorac Surg 2016;102(5):e427-e9.

15) Maher A. Intravenous lobular capillary hemangioma. Ann Vasc Surg 2010;24(7):951.e13-5.

16) Lee MH, Cho SJ, Lee DH, Cho KJ. A case of pyogenic granuloma of the external auditory canal. Korean J Audiol 2008;12(2):129-32.

17) Maddison A, Tew K, Orell S. Intravenous lobular capillary haemangioma: ultrasound and histology findings. Australas Radiol 2006;50(2):186-8.

18) Kwon JN, So BJ, Yun KJ, Roh BS. Intravenous pyogenic granuloma (or lobular capillary hemangioma) developed within the right external Iliac vein. Korean J Vasc Endovasc Surg 2005;21(1):73-7.

19) Zhou H, Zhang J, Yang P, Jiang L, Zhang Y, Wang H, et al. Intravenous lobular capillary hemangioma: report of a case and review of literature. Int J Clin Exp Pathol 2016;9(6):6397-401.

20) Hong SK, Kim CD, Park MH, Hong HJ. A case of bilateral internal jugular phlebectasia. Korean J Otorhinolaryngol-Head Neck Surg 1997;40(9):1348-51.

21) Mickelson SA, Spickler E, Roberts K. Management of internal jugular vein phlebectasia. Otolaryngol Head Neck Surg 1995;112(3):473-5.

22) Livingstone AS. Vascular injuries of the head and neck. Otolaryngol Clin North Am 1983;16(3):671-8. 